\begin{tabular}{|l|l|l||}
\hline \multicolumn{2}{|c|}{ PublisherInfo } \\
\hline \hline PublisherName & $:$ & BioMed Central \\
\hline \hline PublisherLocation & $:$ & London \\
\hline \hline PublisherImprintName & $:$ & BioMed Central \\
\hline \hline
\end{tabular}

\title{
Major study finds no link between gum disease and $\mathrm{CV}$ risk
}

\begin{tabular}{|l|l|l||}
\hline \multicolumn{2}{|c||}{ ArticleInfo } \\
\hline \hline ArticleID & $:$ & 48 \\
\hline \hline ArticleDOI & $:$ & $10.1186 /$ cvm-2001-72050 \\
\hline \hline ArticleCitationID & $:$ & 72050 \\
\hline \hline ArticleSequenceNumber & $:$ & 27 \\
\hline \hline ArticleCategory & $:$ & Paper Report \\
\hline ArticleFirstPage & $:$ & 1 \\
\hline \hline ArticleLastPage & $:$ & 3 \\
\hline \hline & & RegistrationDate : 2001-10-18 \\
ArticleHistory & $:$ & Received \\
\hline \hline ArticleCopyright & $:$ & Biomed Central Ltd2001-3-15 \\
\hline \hline ArticleGrants & $:$ & \\
\hline \hline
\end{tabular}




\begin{tabular}{|l|l|l|}
\hline ArticleContext & $:$ & 1306322 \\
\hline
\end{tabular}

Joanna Lyford, ${ }^{\text {Aff1 }}$

Corresponding Affiliation: Aff1

Aff1 MedWire, UK

Keywords

Cardiovascular disease, periodental disease

\section{Context}

Experts have speculated that oral bacterial infection could move into the systemic circulation and cause chronic inflammation and other proatherogenic processes. The present study set out to investigate whether people with peridontal disease have a greater risk of developing cardiovascular disease.

\section{Significant findings}

They found that self-reported histories of peridontal disease at baseline were not associated with increased risk of CHD an average of 12.3 years later. At follow-up, the investigators reported 797 nonfatal myocardial infarctions, 631 nonfatal strokes, and 614 cardiovascular deaths. For each endpoint, the study had $>90 \%$ power to detect a clinically important increased risk of $50 \%$. Even after adjusting for age and treatment assignment, those physicians who presented with peridontal disease at baseline had slightly elevated, but statistically nonsignificant, relative risks for all three conditions. Moreover, further adjustment for cigarette smoking and other possible CV risk factors reduced the estimates to the null value of 1.0 .

\section{Comments}

The authors suggest that incomplete data on cigarette smoking in previous studies may account for associations between gum disease and CHD risk. 
The authors, also investigated the association of CVD and tooth loss (a marker for severe peridontal disease) and found that rather than being a risk factor for CVD there was an unexpected and statistically significant 39\% reduced risk of cardiovascular death for those who experienced tooth loss during follow-up. They suggested that tooth loss found on follow-up could be a marker of good health compared to baseline tooth loss. Alternatively, they admitted, the result could be a "fluke".

The authors concluded that self-reported peridontal disease may not be an independent risk factor for cardiovascular disease.

\section{Methods}

The authors analyzed self-reported data on 22,071 middle-aged males participating in the Physicians' Health Study I (PHS I) in the USA.

\section{Additional information}

\section{References}

1. Howell TH, Ridker PM, Ajani UA, Hennekens CH, Christen WG: Periodontal disease and risk of subsequent cardiovascular disease in U.S. male physicians. J Am Coll Cardiol. 2001, 37: 445-450. 